\title{
工作機械の熱変形の定式化による簡便な加工誤差補正方法* (連続稼動条件での適用)
}

\author{
金子義 幸*1, 立矢 宏*2, 田村 英 晃*3
}

新庄弘嗣 $* 3$, 磯 部 稔*4

Simple and Effective Method to Compensate Thermal Deformation

of a Machine Tool by Deriving its Approximate Equation

(Application under the Continuous Operating Condition)

Yoshiyuki KANEKO*5, Hiroshi TACHIYA, Hideaki TAMURA,

Hirotsugu SHINJO and Minoru ISOBE

$* 5$ Takamatsu Machinery CO., LTD.,

1-8 Asahigaoka, Hakusan-shi, Ishikawa, 924-8558 Japan

This study presents a simple method to compensate the thermal deformation by measuring temperatures at only a few points of a CNC lathe. We have confirmed the thermal deformation of the main spindle of the lathe strongly depends on changes of temperatures at the headstock and ambient. Therefore, the present study measures the thermal deformation with respect to the temperature changes of these points and considers these relations. From the results, the approximate equation of the thermal deformation dependents on the temperature of the headstock is derived as a function of the temperatures of a few points and the rotational speed of the main spindle. Furthermore, the approximate equation of the thermal deformation of the ball screw is likewise derived as a function of the ball nut and ambient temperatures. By using the estimation value of the thermal deformation obtained from both approximation equations, the work error is compensated. The present study demonstrates the cutting processing in view of the estimated values of the thermal deformation obtained from the derived equations and confirm the work error will be remarkably reduced.

Key Words: Thermal Deformation, Compensation, Machine Tool, Lathe, Spindle, Ball Screw, Headstock

\section{1. 緒 言}

工作機械の熱変形は加工精度に大きな影響を与える ことから，その対策に関してこれまで種々の研究がな されている(1). 従来の熱変形対策としては, 機械の周 囲を恒温環境とする，また，多数の泠却装置を用いて 機械各部を強制冷却する, 熱源を隔離する(2)など, 熱 変形そのものを抑制する方法が一般的に行われている. しかし，これらの対策はコスト，環境への影響といっ た観点からは好ましくない，そこで，熱変形を抑制す るのではなく, ニューラルネットワークや有限要素法 などの数值解析により, 熱変形量を推定し加工量を補 正する方法 (3) (7)やCNC装置の内部情報を利用して工作 機械の熱変形を推定する方法(8), 構造的に熱変形の影 響を小さくする方法(9)などが検討されている. しかし， ニューラルネットワークの構築には数十点におよぶ位 置での温度測定が必要であり, また, 有限要素法によ る解析では工作機械のモデルの作成に多大な労力を要 するため, 従来の熱変形補正の実施は容易でない.

旋盤は機械各部に変形が生じても, 主軸と刃物台間 の相対変位が変化しなければ安定した加工精度が得ら れる，そこで，本論文ではCNC旋盤を対象に主軸と刃

\footnotetext{
* 原稿受付 2006 年 5 月 15 日.

*1 正員, 高松機械工業(株) (焉 924-8558 白山市旭丘 1-8).

*2 正員, 金沢大学大学院自然科学研究科( $920-1192$ 金沢市 角間).

*3 金沢大学大学院自然科学研究科

*4 高松機械工業(株).

E-mail : kaneko@takamaz.co.jp
}

物台間の相対変位に強く影響する主軸部および刃物台 を駆動するボールねじ部の変形をそれぞれ独立で扱う ことで, 熱変形の影響が単純な式で表され, 式中の未 知の定数も少数位置での温度測定結果から決定可能と なることを示す．以上の方法によれば, 従来の熱変形 対策に比べ, 極少数位置での温度測定結果から, 特別 な数值計算法を用いず熱変形の補正が可能となる.

本論文では，本補正方法の有効性をまず恒温環境下 で検討することとし, 旋盤を連続稼働させ, 装置本体 の複数箇所の温度変化と主軸と刃物台との相対距離変 化との関係を明らかにする.さらに，各部の熱変形近 似式を導き, 経時変化切削試験を実施して効果の確認 を行い, 本手法の有効性について示す.

\section{2. 熱変形測定試験}

$2 \cdot 1$ 試験装置試験には高松機械工業(株)製 CNC 旋盤TN2000(10)を使用した。試験装置可動部分の概略 を図1に，主な仕様を表1に示す。試験装置の主軸台の 軸受構成は前側が複列円筒ころ軸受とアンギュラ玉軸 受の組合せであり, 後側は複列円筒ころ軸受である. 刃物台を図1中の $X$ 軸方向に移動するボールねじの仕 様は, ねじ部径が $\phi 32 \mathrm{~mm}$, リードが $6 \mathrm{~mm}$, ねじ部長 さが $280 \mathrm{~mm}$ である.ボールねじの組付は, サーボモー 夕側が単純支持（以下支持側）, 他端が固定支持（以 下固定側）であり, 加工点に近い固定側の軸受が熱変 


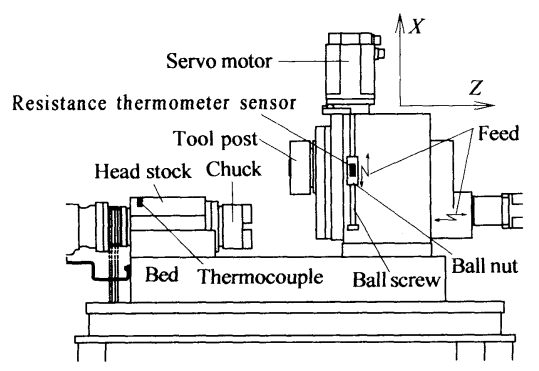

Fig.1 Schematic view of the test machine

Table 1 Specification of the test machine

\begin{tabular}{c|c||c}
\hline \multirow{2}{*}{ Head stock } & Height of the center from floor $(\mathrm{mm})$ & 1570 \\
\cline { 2 - 3 } & Spindle rotational MAX speed $\left(\mathrm{min}^{-1}\right)$ & 4500 \\
\hline \multirow{2}{*}{ Tool post } & Stroke of $X$ axis $(\mathrm{mm})$ & 120 \\
\cline { 2 - 3 } & Stroke of $Z$ axis $(\mathrm{mm})$ & 140 \\
\hline Main motor & Power $(\mathrm{kW})$ & AC 5.5/3.5 \\
\hline Hydraulic motor & Power $(\mathrm{kW})$ & 0.4 \\
\hline \multicolumn{2}{r}{} & Weight $(\mathrm{kg})$ \\
\hline \multicolumn{2}{r}{ Size $:$ height $\times$ width $\times$ depth $(\mathrm{mm})$} & 3200 \\
\hline
\end{tabular}

形の基点となる.ナットにはオフセット予圧方式で約 $1.6 \mathrm{kN}$ の予圧荷重を与え油潤滑を行っている.

主軸部およびボールねじ部の発熱による主軸と刃物 台間の相対距離（以後, 主軸刃物間距離と記す）の変 化を測定するため図2に示すように渦電流式変位セン サを装着したホルダ形の治具を刃物台に，その側面か ら $30 \mathrm{~mm}$ の突き出し量で取り付けた。試験時には主軸 側に検知物を設置するとともに，あらかじめ定めた測 定位㯰へ刃物台を移動し変位センサと検知物間との距 離を測定し主軸刃物間距離とした。なお，試験装置は 室温が $15^{\circ} \mathrm{C}$ から $35^{\circ} \mathrm{C}$ 範囲において $\pm 1{ }^{\circ} \mathrm{C}$ の温度幅で 制御可能な恒温恒湿環境下に設㯰した.

以上の測定方法で, 周囲温度, 稼働条件などを変化 させて, 対象とするCNC旋盤の主軸モータ, 油圧ユ ニット，主軸ハウジング軸受近傍，ボールナット等の 熱源やベッドの前後左右の各点など熱変形に影響を及 ぼすと考えられる合計30简所の温度変化と主軸刃物間 距離の関係を測定し，その相関係数を算出した。詳細 は略すが，いずれの測定条件においても図1に示す主 軸ハウジング上部軸受付近の温度変化と主軸刃物間距 離変化との相関係数が常に 0.98 以上と高い值を示し た。そこで, 主軸部の温度は, 図1に示す主軸ハウジ ング上部軸受付近の温度を代表点として，同简所に熱 電対（T型）を埋め込み測定した。また，ボールね じ部の熱変形は主としてボールナット部のボールとね じ部との摩擦による発熱に起因するとした。そこで, ボールナット部の温度を代表温度とし, 測温抵抗体

（JPt100型）を図1に示す位置に貼付して測定した。

$2 \cdot 2$ 主軸部温度による熱変形測定主軸部温度の 影響を検討するための主軸刃物間距離測定方法を図3で

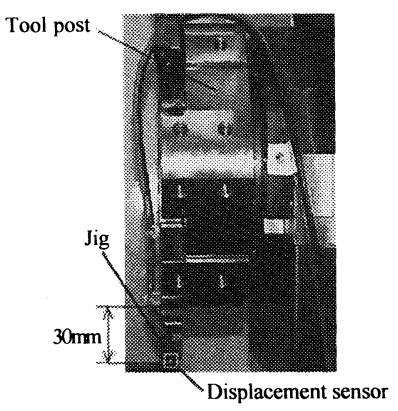

Fig.2 Experimental setup of the displacement sensor

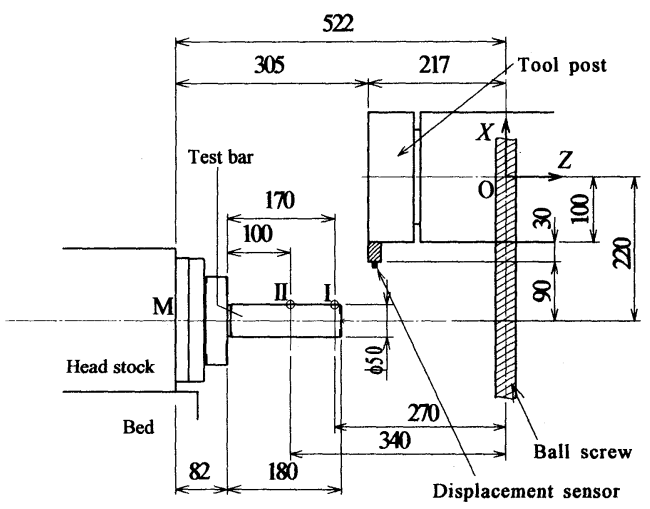

Fig. 3 Method to measure the deformation of the main spindle

説明する. 図3に示すようにNC座標指令が零の位置を点 $O$, 水平方向（送り方向）を $Z$ 軸, 鉛直方向（切込方 向）を $X$ 軸とする $O-X Z$ 座標系を設定する，原点 $\mathrm{O}$ は，主 軸端部軸心である点Mから水平方向に $522 \mathrm{~mm}$, 鉛直方向 上方に $220 \mathrm{~mm}$ 位置である. 主軸には測定部の直径が $50 \mathrm{~mm}$, 測定部の長さが $180 \mathrm{~mm}$ のテストバーを検知物と して取付け，図3に示すようにテストバー上面の点 I お よびII と刃物台との相対距離を主軸刃物間距離として測 定した。点 I およびIIの位置はそれぞれ試験開始時にお いて点OからZ軸方向に-270mmおよび-340mmの位置で あった。

測定は主軸を定速で回転させるとともに1分ごとに常 に同位相で停止させ, 刃物台を変位センサの検出範囲と なる0.5〜 1.0mmの閒となるように点 I または II 上に位 置決めして行った。この時のスライドの送り速度は $400 \mathrm{~mm} \cdot \mathrm{min}^{-1}$ とし, ボールねじ部の発熱による影響が及 ばないようにした。ただし，各試験においてX軸および $Z$ 軸方向の移動指令量は常に一定とした.

刃物台は, 主軸刃物間距離の測定時以外は測定点近傍 に停止させた.この時, 刃物台を駆動するナット温度の 変化は $1.5^{\circ} \mathrm{C}$ 程度と小さく, ボールねじ部の発熱の影響 は無視できるとした．また，あらかじめ行った室温約 23 ${ }^{\circ} \mathrm{C}$ 恒温環境条件下での測定結果から，いずれの場合も 


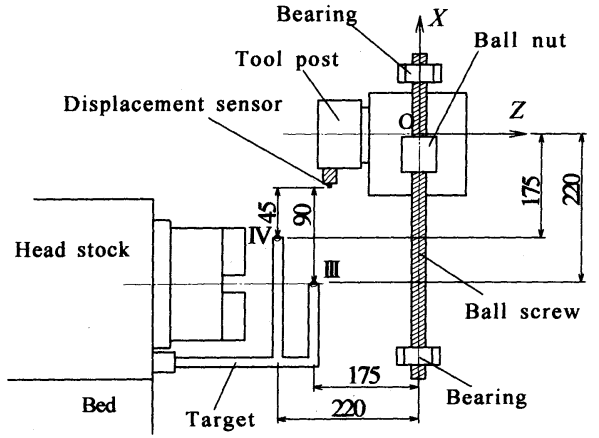

Fig.4 Method to measure the deformation of the $X$-axis ball screw

試験開始後, 約6時間で主軸ハウジング部の温度変化が ほぼ一定となり熱変形も定常状態となる傾向にあっ た．そこで，測定は各条件とも稼働開始から6時間以内 の範囲を対象とした.なお, 機械の電源投入は試験開 始直前に行い, 暖機運転無しとした.

\section{$2 \cdot 3$ ボールねじ部温度による熱変形測定ボール} ねじ部の温度の影響を検討するための主軸刃物間距離 測定方法を図4で説明する. 図4 中のO-XZ座標系は図 3 と同一である. 主軸ハウジング前側端面に測定対象 物として, みがき棒鋼用一般鋼材製のマグネットベー スを取付け, $X$ 軸正方向へ突起した部分の先端の点III よびIVと刃物台との相対距離を測定し主軸刃物間距離 とした．点IIIおよびIVはそれぞれ試験開始時に点Oか らZ軸方向に-175mmおよび-220 mm, $X$ 軸方向に-90mm および-45mmの位置であった。

測定時には, 刃物台を図4に示す点Oから $X$ 軸方向に一 $90 \mathrm{~mm}$ の間を $18 \mathrm{~m} \cdot \mathrm{min}^{-1}$ の送り速度で 1 往復させた後, $1 \mathrm{~m} \cdot \mathrm{min}^{-1}$ で 1 往復させ, さらに, $18 \mathrm{~m} \cdot \mathrm{min}^{-1}$ で 1 往復させ る計 60 秒の 1 サイクル稼動とし, 1 サイクルごとに変位 センサを点IIIまたはIVの変位の検出範囲となる位直へ 送り速度 $400 \mathrm{~mm} \cdot \mathrm{min}^{-1}$ で移動させた.

以上の測定では油圧ユニットやチャッキングシリン ダの作動油の循環による発熱が主軸台の変形に影響し ないように主軸台のチャッキングシリンダへの油圧配 管を取り外した. また, 主軸部温度の熱変形への影響を 抑制するために主軸は常に停止状態とした.

なお，あらかじめ行った室温約 $23^{\circ} \mathrm{C} の$ 恒温条件下で の測定結果から, 試験開始後, 約 3 時間でボールナッ トの温度変化がほぼ一定となり熱変形も定常状態とな る傾向にあったため, 测定は各条件とも稼働開始から 3 時間以内の範囲を対象とした.この場合も,機械の電 源投入は試験開始直前とし暖機運転無しとした.

\section{3. 主軸部の熱変形の近似}

$3 \cdot 1$ 主軸部の温度による熱変形本論文では熱変 形を表す主な要因として主軸部温度変化の他に, 工作

\begin{tabular}{|c|c|c|c|}
\hline No. & $\begin{array}{c}\text { Spindle speed } N \\
\left(\min ^{-1}\right)\end{array}$ & $\begin{array}{l}\text { Initial temperature of } \\
\text { head stock } T_{h 0}\left({ }^{\circ} \mathrm{C}\right)\end{array}$ & $\begin{array}{c}\text { Ambient } \\
\text { temperature } T_{a}\left({ }^{\circ} \mathrm{C}\right)\end{array}$ \\
\hline 1 & 1000 & 23.7 & 23.1 \\
\hline$\frac{2}{2}$ & 1000 & 25.0 & 24.1 \\
\hline$\frac{2}{3}$ & 2000 & 23.8 & 22.7 \\
\hline 4 & 2000 & 24.4 & 23.5 \\
\hline 5 & 3000 & 23.4 & 23.0 \\
\hline 6 & 3000 & 24.5 & 22.7 \\
\hline$\frac{\pi}{7}$ & 4000 & 23.4 & 22.4 \\
\hline 8 & 4000 & 24.6 & 23.8 \\
\hline 9 & 4000 & 24.7 & 21.9 \\
\hline 10 & 4000 & 24.9 & 22.6 \\
\hline 11 & 4000 & 21.7 & 22.8 \\
\hline 12 & 4000 & 18.9 & 23.0 \\
\hline 13 & 4000 & 19.3 & 19.9 \\
\hline 14 & 4000 & 20.5 & 17.9 \\
\hline 15 & 4000 & 20.7 & 14.8 \\
\hline 16 & 4000 & 20.8 & 19.0 \\
\hline
\end{tabular}

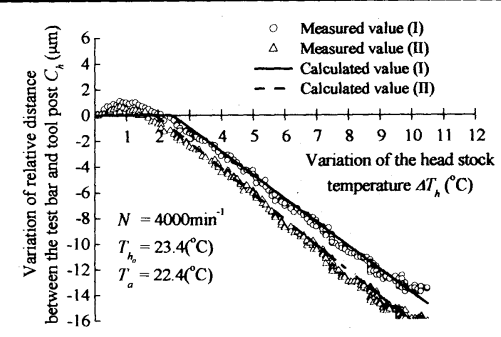

Fig.5 Changes of the relative distance with the headstock temperature 機械の主要な稼㗢条件である主軸回転速度 $N$, 機械周囲 温度 $T_{a}$ および主軸部初期温度 $T_{h 0}$ に注目し，これらの条 件を変化させて主軸刃物間距離を測定した。なお, 先 述のとおり測定は恒温環境下で行い, 測定時の周囲温 度の変化は土 $1^{\circ} \mathrm{C}$ 以下であった. そこで, 機械周囲温度 は測定中一定であるとみなし, 測定開始時の温度を $T_{a}$ とした．各試験時の条件は表2に示すとおりである。

図5に主軸回転速度 $N$ を $4000 \mathrm{~min}^{-1}, T_{h 0}$ を $23.4^{\circ} \mathrm{C}, T_{a}$ を $22.4^{\circ} \mathrm{C}$ とた表 2 に示す7番の測定条件における点 I お よびII の主軸刃物間距離変化量 $C_{h}(\mu \mathrm{m})$ を示す. 同図よ り試験開始直後, 主軸部温度変化量 $\Delta T_{h}$ の增加とともに $C_{h}$ はわずかであるが増加（加工径が太くなる方向に変 化）し，その後， $\Delta T_{h}$ に比例して $C_{h}$ は単調に減少(加工 径が細くなる方向に変化)していくことがわかる．この 傾向は他の試験条件においても同じであった.

そこで本論文では $\Delta T_{h}$ と $C_{h}$ との関係を図6に示すよう に近似する．すなわち，試験開始直後に生じる主軸刃 物間距離の増加は全体の変形に比べて小さく無視でき るとし, 主軸部温度変化量がある值 $t_{o}$ に達した後, 主 軸刃物間距離が線形に減少していくと仮定して，その 変化量 $C_{h}(\mu \mathrm{m})$ を $\Delta T_{h}\left({ }^{\circ} \mathrm{C}\right)$ を変数として次式で表す.

$$
C_{h}=A \Delta T_{h}+B \cdots \cdots(1)
$$

以後, 主軸刃物間距離がほぼ線形に減少する部分を線 形変形領域, また, 同領域が開始する主軸温度変化量 $t_{o}$ を変形開始温度と呼ぶ. Aは線形変形領域の傾きであ り，Bは線形変形領域を式(1)に示す一次式で近似した場 


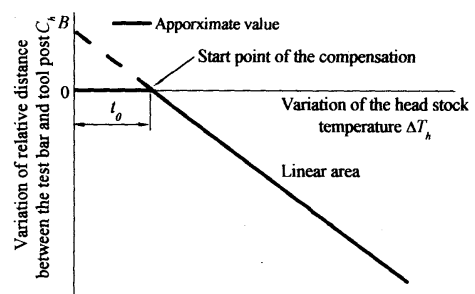

Fig.6 Schematic graph of the relation between the headstock temperature and relative distance

合の切片である.AおよびBが決定されれば，図6に示し た $t_{o}$ が決定され $C_{h}$ が得られる. 以下では, $A$ およびBの 值を主軸部や機械周囲の温度, 主軸回転速度等を変数 として表すことを検討する.

$3 \cdot 2$ 線形变形領域の定式化測定結果を基に主軸 刃物間距離が減少する線形変形領域の傾きと主軸部温 度等との関係を調べる. そのために各測定結果から， 変形開始温度 $t_{o}$ を零として前節で述べた線形変形領域の みを抽出し比較検討する.

まず，主軸回転速度 Nの影響を検討するため，表 $2 に$ 示す測定条件から主軸部初期温度 $T_{h o}$ が $24^{\circ} \mathrm{C}$ 付近, 機械 周囲温度 $T_{a}$ が $23^{\circ} \mathrm{C}$ 付近で, 主軸回転速度が 1000,2000 , $3000,4000 \mathrm{~min}^{-1}$ である 1，3，5，7番の測定結果を選択 し比較する.これらの条件で測定された点 I における 測定結果から, 温度 $t_{o}$ を零として線形变形領域のみを 抽出し図7に示す.

同図より, 主軸回転速度にかかわらず線形変形領域 の傾きはほぼ同一である.また,この傾向は後述の図 12 にも示すとおり点 II の位置においても同じである，そ こで，本論文では線形変形領域の傾きは主軸回転速度 に依存しないとする．以後は主軸回転速度が $4000 \mathrm{~min}^{-1}$ の場合の測定結果を用いて他の条件の影響を検討する.

主軸回転速度を $4000 \mathrm{~min}^{-1}, T_{a}$ を約 $22.5^{\circ} \mathrm{C}$ とした 7,12 番の試験結果を用い, $T_{h o}$ に対する点 $\mathrm{I}$ での線形変形 領域の変化を図8に示し検討する。同図より主軸部初期 温度が $18.9^{\circ} \mathrm{C}$ 場合に比べて $23.4^{\circ} \mathrm{C}$ である場合の方が線 形変形領域の傾きが大きい. 寸なわち, 線形変形領域 の変化は主軸部初期温度に依存し主軸部初期温度が増 加すれば線形変形領域の傾きも大きくなる.

主軸回転速度を $4000 \mathrm{~min}^{-1}, T_{h o}$ を約 $21^{\circ} \mathrm{C}$ とした 15 , 16番の試験結果を用い, $T_{a}$ に対する点 II での線形変形 領域の変化を図9に示し検討する. 同図より機械周囲温 度が $19.0^{\circ} \mathrm{C}$ の場合に比べて $14.8^{\circ} \mathrm{C}$ である場合の方が線形 変形領域の傾きが大きい，すなわち，線形変形領域の 変化は機械周囲温度に依存し, 機械周囲温度が低下す れば線形変形領域の傾きが大きくなる.

以上の傾向は表2に示す全ての条件下において, 点 I およびIIの位置のいずれの位置でも同様であったす

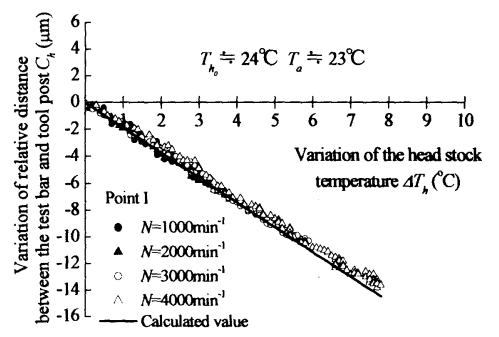

Fig.7 Change of the relative displacement with the spindle speed

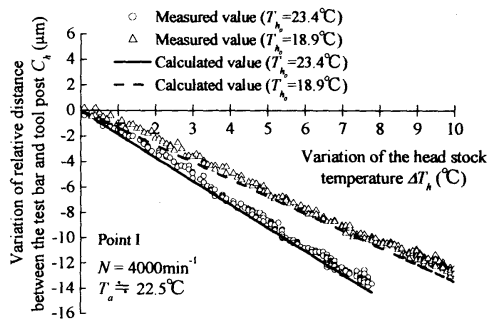

Fig.8Change of the relative displacement with the initial temperature of the headstock

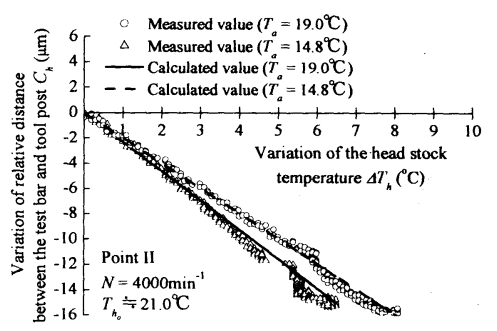

Fig.9Change of the relative displacement with the ambient temperature なわち本論文の測定範囲では線形変形領域の傾きは主 軸回転速度 $N$ に依存せず, 主軸部初期温度 $T_{h 0}$ およ゙機 械周囲温度 $T_{a}$ に依存すると考えられる.そこで, 式(1) 中の係数 $A$ を $T_{h 0}$ および $T_{a}$ をパラメータとして表すこと を検討する。

係数 $A$ と $T_{h 0}$ および $T_{a}$ との関係を把握するために, 表 2 に示す主軸の回転速度が4000 $\mathrm{min}^{-1}$ である測定結果より

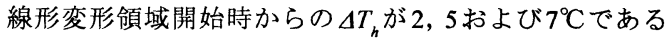
場合の $T_{h o}, T_{a}$ と $C_{h}$ との関係を求め, 点 I での結果を ○，ロおよびムでそれぞれ図10，11に示す．なお，図 10には表2の7，9～12番, 図11には12〜16番の結果を用 いた.ただし, 15 番の結果では $\Delta T_{h}$ の最大值が $7^{\circ} \mathrm{C}$ 末 満であったため, 図11において $T_{a}$ が $14.8^{\circ} \mathrm{C} て ゙ の C_{h}$ は2 点 のみである.それぞれの結果に対して最小二乗法によ り線形近似した直線を同図中に比較のため示す. 図 10,11より $C_{h}$ は $T_{n o}, T_{a}$ に対してほぼ線形に変化してい る. 点 II の位置の結果においても同様な結果が得られ た.そこで, 式(1)中の定数 $A\left(\mu \mathrm{m} \cdot{ }^{\circ} \mathrm{C}^{-1}\right)$ を $T_{h 0}\left({ }^{\circ} \mathrm{C}\right)$ および $T_{a}\left({ }^{\circ} \mathrm{C}\right)$ の一次式とし次式で表す.

$A=a_{1}+a_{2} T_{h_{0}}+a_{3} T_{a} \cdots \cdots(2)$

ここで, $a_{i}(i=1 \sim 3)$ は末知の係数である. 


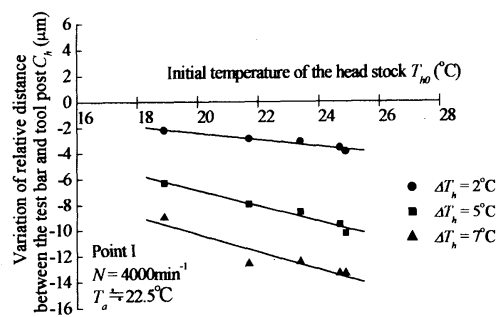

Fig.10 Relation between the initial temperature of the headstock and relative displacement

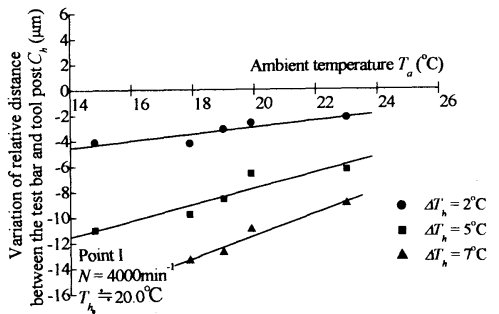

Fig.11 Relation between the ambient temperature and relative displacement

Table 3 Value of $a$

\begin{tabular}{c|c|c}
\hline & I & II \\
\hline$a_{1}\left(\mu \mathrm{m} /{ }^{\circ} \mathrm{C}\right)$ & $-9.95 \times 10^{-1}$ & -1.178 \\
\hline$a_{2}\left(\mu \mathrm{m} /{ }^{\circ} \mathrm{C}^{2}\right)$ & $-1.01 \times 10^{-1}$ & $-1.11 \times 10^{-1}$ \\
\hline$a_{3}\left(\mu \mathrm{m} / \mathrm{C}^{2}\right)$ & $6.77 \times 10^{-2}$ & $7.89 \times 10^{-2}$ \\
\hline
\end{tabular}

式(1)において定数 $B$ を零とし定数 $A$ に式(2)を代入し て得られた式により, 表2に示す全条件下の点 Iおよび IIにおける測定值の線形変形領域を線形最小二乗法で それぞれ近似し係数 $a_{i}$ を決定した. 得られた点 I および II の位置に対する $a_{i}$ の值を表 3 に示す.

表 3の值を用い図7〜9に示す測定結果の線形変形領 域に対する $C_{h}$ を式(1)より求め同図中にそれぞれ実線, 破線で示す。これらの図より，いずれの条件において も式(1)による值は測定結果によく一致している.

$3 \cdot 3$ 変形開始温度 $t_{0}$ の検討 図6に示したように, 本論文では主軸部の温度変化量が $t_{o}$ 以上となった場合 に熱変形が生じるとする。したがって，熱変形を予測 するためには $t_{0}$ の值を表す式を導く必要がある.

$t_{0}$ の值は熱変形を近似する式(1)および図6より, 式(1) 中の定数 $A$ およびBによって決定される. 定数 $A$ は式(2) で表したので，ここでは定数 $B$ 表す式を導く．そのた めに，各測定結果において図12に示すように線形変形 領域を横軸の主軸部温度変化量 $\Delta T_{h}$ に対する一次式で近 似し，その切片 $B$ を求める. なお，図12は点IIでの測定 值より得た結果である. 同じ処理を以下に示す測定結 果に対して行い切片Bの変化を検討した。

図 13 に主軸部初期温度が約 $24^{\circ} \mathrm{C}$, 機械周囲温度が約 $23^{\circ} \mathrm{C}$ 付近とほぼ等しく主軸回転速度が異なる表 $201 〜$ 7, 10番の測定結果から求めた点拈よびIにおけるBの 值を○およびムで示す. 同図より切片Bの值は主軸回転

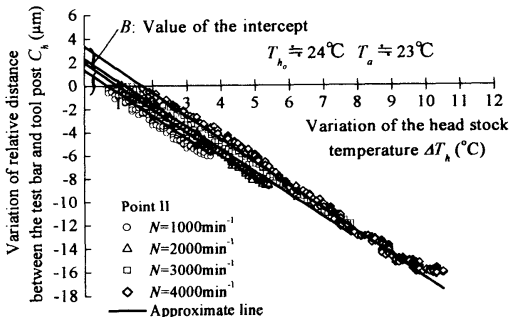

Fig.12 Linear approximation of the relative distance

速度とともに単調に増加することがわかる.

図 14 に主軸回転速度が $4000 \mathrm{~min}^{-1}$, 機械周囲温度が約 $22.5^{\circ} \mathrm{C}$ 付近であり, 主軸部初期温度が異なる7, 9 12 番の測定結果から求めた点IおよびIIにおける $B$ の值を ○およびムで示す. 同図より切片 $B$ の值は主軸部初期温 度とともに単調に増加することがわかる.

図 15 に主軸回転速度が $4000 \mathrm{~min}^{-1}$, 主軸部初期温度が 約 $20^{\circ} \mathrm{C}$ 付近であり，機械周囲温度が異なる12〜16番の 測定結果から求めた点 I およびIにおける $B$ の值を○ およびムで示す.同図より切片Bの值は機械周囲温度の 増加に対して単調に減少することがわかる.

以上の結果より切片 $B$ の值は主軸回転速度 $N$, 主軸部 初期温度 $T_{h 0}$ および機械周囲温度 $T_{a}$ に依存し, 図 $13 \sim$ 15に示すように,これらに対してほぼ線形に変化する. そこで, 切片 $B$ を $N\left(\mathrm{~min}^{-1}\right), T_{h 0}\left({ }^{\circ} \mathrm{C}\right)$ および $T_{a}\left({ }^{\circ} \mathrm{C}\right)$ を変数 として以下の一次式で表す.

$$
B=b_{1} N+b_{2} T_{h_{0}}+b_{3} T_{a}+b_{4} \quad \cdots \cdots(3)
$$

ここで $b_{i}(i=1 \sim 4)$ は未知の係数である. 表 2 に示した各 測定結果において図 12 と同じく線形変形領域を $\Delta T_{h}$ に 対する一次式で近似し求めた点 I および IIでの切片 $B$ の值に対して式(3)を用い線形最小二乗法で近似し決定 した $b_{i}$ の值を表 4 にそれぞれ示す. また，表 4 に示す $b_{i}$

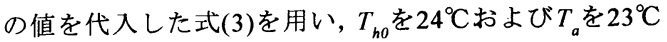
として得た值を図 13 に, $T_{a}$ を $22.5^{\circ} \mathrm{C}$ とて得た值を図 14 に， $T_{h 0}$ を $20^{\circ} \mathrm{C}$ とて得た值を図 15 にそれぞれ示す. 実線が点に対する值であり, 破線が点Iに対する值で ある. 図13〜15より，式(3)は $N, T_{h 0}$ および $T_{a}$ に対する 切片 $B$ の変化におおよそ一致していることがわかる。

以上の結果から本論文では対象とする旋盤の主軸刃 物間距離変化量 $C_{h}$ を式(2)および(3)を代入した式(1)で近 似する。ただし，式(1)は $C_{h}$ が負となる範囲，すなわ ち, $\Delta T_{h}$ が $t_{o}$ 以上となる範囲で適用可能であり, $\Delta T_{h}$ が $t_{o}$ 以下では $C_{h}$ を零とする.

図 5に示した測定值の条件下で式(2)および(3)を代入 した式(1)より得られる点 I および II での熱変形量計算 值を同図中に実線および破線で示す. 図 5 に示すよう に, 線形変形領域および熱変形が負となる線形変形領 域の開始点がいずれの測定值ともよく一致しており提 


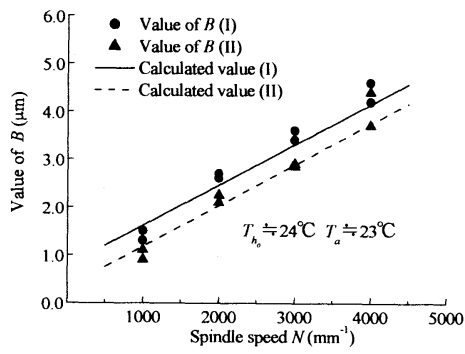

Fig.13 Relation between the spindle speed and value of $B$

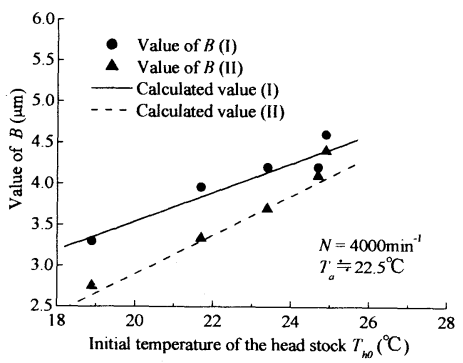

Fig.14 Relation between the initial temperature of the headstock

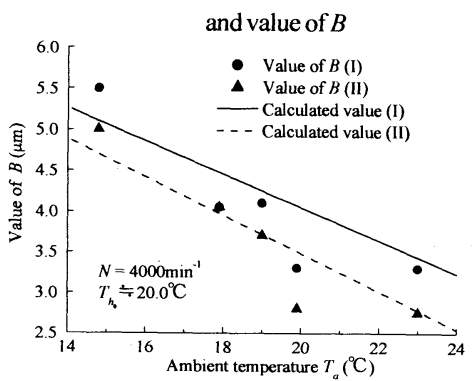

Fig.15 Relation between the ambient temperature and value of $B$

案する式の妥当性が確認できる.

\section{4. ボールねじ部の熱変形の近似}

\section{$4 \cdot 1$ ボールねじ部の熱変形測定 図 4 に示す刃物} 台の運動によって生じるボールねじ部の熱変形の影響 を2.3で述べた方法により測定した．なお，ボールねじ 部の熱変形はボールナット部の温度上昇により直接生 じるとして主軸刃物間距離と同部分の温度との関係の みを検討し，室温などの影響は考慮しなかった。

測定された主軸刃物間距離とボールナット温度との

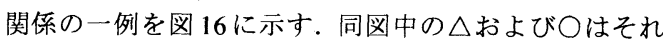
ぞれ図4中の点IIIおよびIVにおける主軸刃物間距離の変 化を示している.なお, 他の測定においてもほぼ同様な 結果が得られた.

図 16 の測定結果よりボールねじ軸方向中央部の点IV において $C_{b}$ が大きく変化し，また，ボールねじ端部の 点IIIでの変化は小さい，本試験装置の刃物台を駆動す るボールねじは点III側を固定とした両端支持構造と なっており, 以上のように熱変形の影響は主として固

\begin{tabular}{l|c|c}
\multicolumn{3}{|c}{ Table 4 Value of $b_{\text {; }}$} \\
\hline & I & II \\
\hline$b_{1}\left(\mu \mathrm{m} / \mathrm{mm}^{-1}\right)$ & $8.42 \times 10^{-4}$ & $8.53 \times 10^{-4}$ \\
\hline$b_{2}\left(\mu \mathrm{m} /{ }^{\circ} \mathrm{C}\right)$ & $1.75 \times 10^{-1}$ & $2.38 \times 10^{-1}$ \\
\hline$b_{3}\left(\mu \mathrm{m} /{ }^{\circ} \mathrm{C}\right)$ & $-2.03 \times 10^{-1}$ & $-2.34 \times 10^{-1}$ \\
\hline$b_{4}(\mu \mathrm{m})$ & 1.24 & $-9.59 \times 10^{-3}$ \\
\hline
\end{tabular}

定点から離れるに従い增加すると考えられる.

ボールねじ軸方向中央付近である点IVで測定した変 形量は $\Delta T_{b}$ に対して増減を繰返し非線形な挙動を示して いる.このような変形の原因として推測であるが, 本装 置のボールねじの組付構造の影響が考えられる。すな わち, 試験開始直後は比較的拘束力の弱い支持側に ボールねじの熱変形による伸びが生じるが，徐々に支 持側の反力が増加し，途中からは反対に固定側に熱変 形による伸びが表れ，さらに，固定側の反力が増大する と再び支持側に変化が表れると考えられる.

$4 \cdot 2$ ボールねじ部熱変形近似式図16より,ボー ルナット温度に対する主軸刃物間距離の変化は非線形 であり, 主軸部熱変形近似式のように線形式での近似 が困難である.そこで,ボールねじ部の熱変形は取り报 いが容易でさまざまな曲線を表し得る多項式を用いて 近似する.

すなわち, 点III での変形は固定部付近でありほぼ零 付近を示しているため, 同箇所での熱変形量は零とす

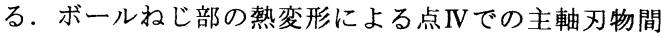
距離変化量 $C_{b}(\mu \mathrm{m})$ を表す近似式をボールナット温度変 化 $\Delta T_{b}\left({ }^{\circ} \mathrm{C}\right)$ を変数とした次式に示す多項式とする.

$$
C_{b}=\sum_{i=0}^{n} p_{i} \Delta T_{b}^{i} \ldots \ldots \ldots
$$

$n$ は多項式の次数, $p_{i}\left(\mu \mathrm{m} \cdot{ }^{\circ} \mathrm{C}^{-i}\right)$ は末知の係数であり, 測 定値と近似値との残差二乗和が最小となるように Householder 法で決定する. なお, 多項式の次数が増加 するにつれ残差二乗和は減少するが誤差までも近似し 式の取り扱いも困難となる. そこで, 本論文では最適な 次数を AIC（赤池情報量規準）(11)で決定する.

図16に示す点IVでのボールねじ部の熱変形による主 軸刃物間距離の変化を含む4つの測定結果を近似対象と し, 式(4)の次数 $n$ を 1 から增加させ各次数の式を用いて 線形最小二乗法で $p_{i}$ を決定するとともに AIC を求め比 較した. その結果, 9次式が最適と評価された. そこで, 式(4)を9次式とし $p_{i}(i=0 \sim 9)$ を表 5 に示す值とした. 同 式による近似值を図16に実線で示す. 図16のように式 (4)はボールねじ部の熱変形をよく表している.

\section{5. 補正方法および補正効果の確認}

$5 \cdot 1$ 補正方法 以上で導いた $2 つ$ 近似式で対象 とする旋盤の加工誤差を補正する. なお, 式(1)からは 点 I, II での, また, 式(4)からは点III, IVでの変形量 


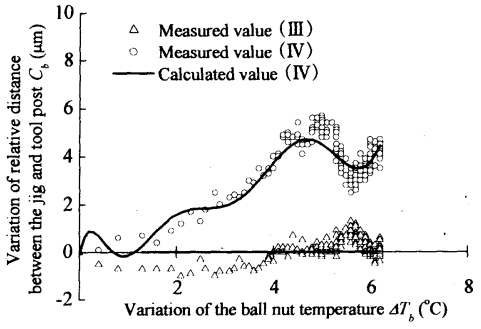

Fig.16 Relation between the ball nut temperature and relative displacement

Table 5 Coefficients of Equation (4)

\begin{tabular}{c|c|c|c|c|c}
$\sum_{\text {Value }}$ & $p_{0}$ & $p_{1}$ & $p_{2}$ & $p_{3}$ & $p_{4}$ \\
\hline & $-1.00 \times 10^{-1}$ & $1.02 \times 10$ & $-3.38 \times 10$ & $4.24 \times 10$ & $-2.61 \times 10$ \\
\hline Value & $p_{5}$ & $p_{6}$ & $p_{7}$ & $p_{8}$ & $p_{9}$ \\
\hline 8.89 & -1.74 & $1.92 \times 10^{-1}$ & $-1.08 \times 10^{-2}$ & $2.28 \times 10^{-4}$ \\
\hline
\end{tabular}

Table 6 Cutting test condition

\begin{tabular}{c|c|c}
\hline & Rough processing & Finishing \\
\hline Spindle speed & $2000,4000 \mathrm{~min}^{-1}$ & $2000,4000 \mathrm{~min}^{-1}$ \\
\hline Cutting depth (radius) & $0.1 \mathrm{~mm}(2 \mathrm{times})$ & $0.05 \mathrm{~mm}$ \\
\hline Feed speed & $0.1 \mathrm{~mm} / \mathrm{rev}$ & $0.05 \mathrm{~mm} / \mathrm{rev}$ \\
\hline Environment & Dry & Dry \\
\hline Cycle time & \multicolumn{2}{|c}{$60,45 \mathrm{sec}$. }
\end{tabular}

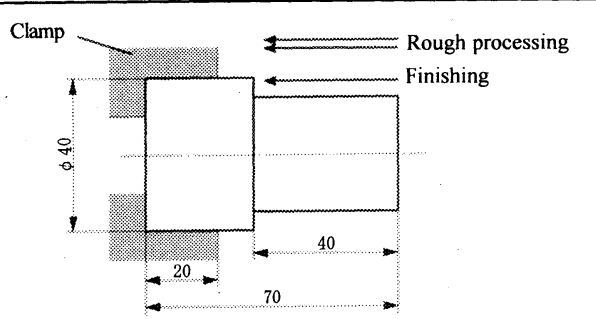

Fig.17 Schematic view of the cutting test piece

の近似值が得られるが, ワークの加工位置は, 図 3 にお いて $Z$ 軸方向に $-300 \mathrm{~mm}$ から $-340 \mathrm{~mm}$ の範囲であり，ま た, $X$ 軸方向に関してはワークの径とともに変化し，こ れらの位置と必ずしも一致しない. そこで, 加工位置で の熱変形量近似值は主軸部，ボールねじ部それぞれに おける2点での測定位置から線形補間を行い算出する.

\section{$5 \cdot 2$ 試験方法および結果補正式の効果を確認す} るため, 経時変化切削試験を実施する. 切削条件を表 6 に, 試験片形状を図 17 に示す. 被削材は, 直径 $40 \mathrm{~mm}$, 長さ $70 \mathrm{~mm}$ の C3604BD材を用い, 切削長は $40 \mathrm{~mm}$ とし た。試験条件は, (1)補正なし, (2)主軸部熱変形補正のみ 実施, (3)ボールねじ部熱変形補正のみ実施, (4)主軸部, ボールねじ部両方の熱変形補正を実施の4通りとした. 主軸回転速度は $2000 \mathrm{~min}^{-1}$ と $4000 \mathrm{~min}^{-1}$ の 2 通りとした. 試験開始から 30 分後までは 5 分毎に, それ以降は 10 分 毎に合計 43 個のワークを使用して実切削を行い, その 間は切削プログラムを繰返しランニング運転させ, 連 続 6 時間の試験とした.

補正は加工前の主軸部温度, ボールナット温度, 周囲

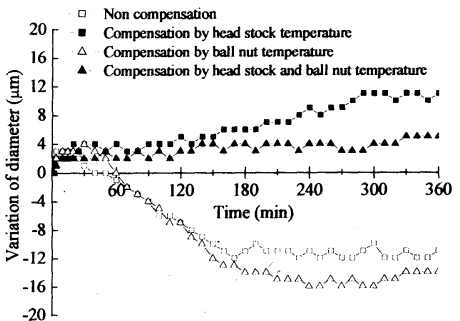

(a) Spindle speed $2000 \mathrm{~min}^{-1}$

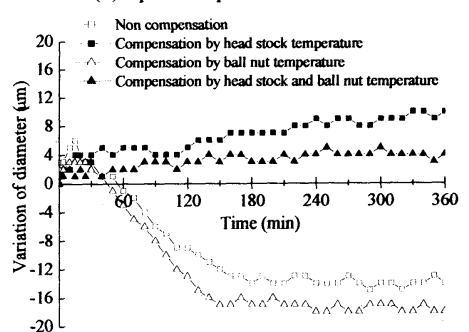

(b) Spindle speed $4000 \mathrm{~min}^{-1}$

Fig.18 Experimental results of the continuance cutting test 温度を測定し, 式(1),(4)からその時点での各部の補正 值を算出し, NC装置のオフセット機能へ入力して補正 を行った.なお, 本試験実施時には,この機械に実施し ている気化熱冷却と断熱対策による熱変形抑制を敢え て実施せず，大きな変形の発生をあらかじめ許容させ た状態としたことを述べておく.

補正効果を確認するためのワークの加工径の測定は, 切削熱の影響を除去するため, 試験の翌日以降マイク ロメータで行った．測定位置は図 17 に示すワークの先 端部分とした。図 18 に主軸回転速度 $2000 \mathrm{~m} \mathrm{in}^{-1}$ と $4000 \mathrm{~min}^{-1}$ の場合の結果を示す. 同図より (1)補正なしの 場合, 加工径変化量幅は主軸回転速度 $2000 \mathrm{~min}^{-1}$ 時は約 $15 \mu \mathrm{m}, 4000 \mathrm{~min}^{-1}$ では約 $21 \mu \mathrm{m}$ であったが, (4)主軸部, ボールねじ部両方の熱変形補正実施の試験ではそれぞ れ約 $5 \mu \mathrm{m}$ となり, 変化量幅をそれぞれ約 $67 \%, 75 \%$ 減 少することができた.なお, (3)のボールねじ部熱変形補 正のみ実施の場合，(1)の補正なしに比べて変化が大き くなっている.これは,ボールねじ部と主軸部の熱変形 が反対方向に生じるためであり，いずれか一方のみの 補正では加工誤差が増大することもあり，両方の熱変 形を考慮することで適切に補正が行えることがわかる.

以上の結果より，本論文の条件下では対象とした $\mathrm{CNC}$ 旋盤の熱変形が少数筒所の温度を主要な変数とし 導いた2つの簡便な近似式より容易に補正可能である.

\section{6. 結 言}

本論文で得られた結果を以下に要約する.

(1)旋盤の加工精度に影響を与える要因として, 主軸部 およびボールねじ部の熱変形を独立して検討すること とし, 各部の温度変化一相対距離変化関係を測定した。 
(2)主軸部熱変形測定結果から, 主軸回転速度, 主軸部 初期温度および機械周囲温度を変数とする主軸部熱変 形補正式を導いた。

(3)ボールねじ部の熱変形の測定結果には非線形性が強 く現れたため, 多項式形の補正式を検討し, 次数を AIC により決定した。

(4)C3604BD材による経時変化切削試験を行い, 以上で 得られた主軸部およびボールねじ部の熱変形近似式よ り得られる値を加え合わせ補正值として用い加工誤差 を測定した．その結果，加工径の変化量幅を約 $70 \%$ 低 減することができ，本手法の有効性を確認した．

今後は，一般工場環境下のような周囲温度が変化す る環境での適用の検証，統計的手法による様々な機種， 温度条件, 稼動条件に対して熱変形の近似式を決定す る汎用的な手法の確立を課題とする。

\section{参考文献}

(1) Senda, H. et al., Estimation of Thermal Displacement of Machine Tool Spindles for Mass Production (1st Report), Transactions of the Japan Society of Mechanical Engineers, Series C, Vol 70, No. 698,(2004), pp.2961-2965

(2) Itoh,Y., Moriwaki,T., Engineering of Machine Tool (in Japanese), (1989), p.46, Corona Company

(3) Chen, L. et al., Positioning Accuracy of CNC Machine Tools (Thermal Effect Prediction Using Neural Network), Transactions of the Japan Society of Me- chanical Engineers, Series C, Vol 62, No. 599,(1996), pp.2686-2991.

(4) Moriwaki,T.,Zhao,C., Prediction of Thermal Deformation of Machining Center by Applying Neural Network, Transactions of the Japan Society of Mechanical Engineers, Series C, Vol 58, No. 550,(1992), pp.1932-1937.

(5) Moriwaki,T. et al., Estimation of Thermal Deformation of Machine Tool by Applying Neural Network (Improvement of Estimation Accuracy by Utilizing Time-Series Data of Temperature on Machine Surfaces), Transactions of the Japan Society of Mechanical Engineers, Series C, Vol 61, No. 584, (1995), pp.1691-1696.

(6) Mitsuishi,M. et al., Development of a High-Precision Machining Center sing Neural Networks and Genetic Algorithm), Transactions of the Japan Society of Mechanical Engineers, Series C, Vol61, No. 591,(1995), pp.4517-4522.

(7) Tanabe,1. et al., Simple and Intelligent Control Using Neural Network About Thermal Deformation of a Machine tool, Transactions of the Japan Society of Mechanical Engineers, Series C, Vol 70, No. 698, (2004), pp.2954-2960.

(8) Shamoto,E. et al., Estimation of Thermal Deformation of Machine Tool by Utilizing Available Information in CNC Unit, Transactions of the Japan Society of Mechanical Engineers, Series C, Vol 69, No. 686,(2003), pp.2775-2782.

(9) Imai,N. et al., Method of Structure Element Design about Machine Tool of Thermal Deformation Free, Proceedings of 2003 years Spring Meeting of the Japan Society for Precision Engineering, (2003-3), pp.193.

(10)New Energy and Industrial Technology Development Organization, Takamatsu Machinery CO., LTD., Development of a Lathe with High Precision and Conservation of Energy Using Natural Phenomenon, Result Report of 2000 years Development of Rationalizing to Use of Energy for Machine Tool (in Japanese),(2001-3), pp.47-49

(11) Toyoda, T., Information Physics, (1997), pp.111-124., Kodansha Scientific 